\title{
ORIGINAL RESEARCH ARTICLE \\ Communities of aquatic organisms in the system of ecological monitoring of streams at the Vostochny Cosmodrome (Russia)
}

D.M. Bezmaternykh*, V.V. Kirillov, G.V. Vinokurova, O.N. Vdovina, N.I. Ermolaeva, E.Yu. Zarubina, A.V. Kotovschikov, E.Yu. Mitrofanova, A.Ve. Puzanov

Institute for Water and Environmental Problems SB RAS, Barnaul, Russia.E-mail: bzmater@mail.ru

\begin{abstract}
The current data on the ecological state of streams at the launch site of the Vostochny Cosmodrome with the use of biological indicators are presented. Recommendations on the surface water biomonitoring of the cosmodrome and the booster rocket drop zones are given. It is shown that the system of biological monitoring of the cosmodrome, as a part of the Roscosmos environmental monitoring, should be coordinated with the Roshydromet monitoring.

Keywords: Bioindication; Biomonitoring; Vostochny Cosmodrome; Zeya River BasinO
\end{abstract}

\section{ARTICLE INFO}

Received: 23 April 2021

Accepted: 29 June 2021

Available online: 8 July 2021

\section{COPYRIGHT}

Copyright $(\mathrm{C} 2021$ D.M. Bezmaternykh, et al.

EnPress Publisher LLC. This work is licensed under the Creative Commons Attribution-NonCommercial 4.0 International License (CC BY-NC 4.0).

https://creativecommons.org/licenses/by-nc/ $4.0 /$

\section{Introduction}

The Vostochny Cosmodrome is a new Russian spaceport in the Amur Oblast, in the Russian Far East. Its construction began in 2011, and in April 2016 it was put into operation ${ }^{[1]}$. The launch site of the cosmodrome is located in the Zeya river basin.

\subsection{Object of research}

The river network of the launch site is represented mainly by small rivers. The site partly includes the watersheds of the Zeya first- and second-order tributaries (Bolshaya Pera, Ora and Dzhatva rivers). Besides, there are watersheds of other first-order right tributaries of the Zeya (Galchikha, Kamenushka, Iur rivers, and Iversky stream), and the first-order tributaries of Bolshaya Pera river (Zolotoy, Serebryany, Medny streams) and Ora river (Okhotnichy and Nikolaevsky streams).

The hydrological regime of rivers is distinguished by multiple rain floods, water level fluctuation with significant amplitudes throughout the ice-free period, the absence of winter water runoff in small streams as a result of through freezing. These features of water ecosystems are mainly determined by a monsoon climate. The available data are evidence of low water mineralization, minor content of biogenic substances, and low organic pollution ${ }^{[2,3]}$.

The construction of the cosmodrome on particular areas of watersheds resulted in the change of surface runoff and water regime of small streams, up to the formation of drainless sites. The construction of roads led to the disturbance of some parts of the floodplain and coast line, and the construction of linear infrastructure facilities caused a delay of groundwater migration ${ }^{[4]}$. 


\subsection{Biological monitoring of freshwater eco- systems}

The environmental monitoring implies the long-term observations, the assessment and forecast of the environment state and its pollution. The methods of physical and chemical analysis currently used cannot provide a full assessment of the human impact on the environment. Firstly, these methods reflect the current situation during the sampling, while the biological method allows to reveal impact on water body in the previous analysis time. Secondly, it is impossible to determine all known and unknown types of water pollutants; biological objects respond to all types of pollution regardless of their nature and provide an integral indicator of water quality as a habitat. The biological analysis can use different groups of hydrobionts depending on the research objectives $^{[5,6]}$.

Phytoplankton can serve as an indicator of the water body trophicity since there is a direct relationship between the phytoplankton productivity and phosphorus content. Zooplankton is characterized by rapid response to environmental changes that allows us to use it as a sensitive indicator of rapid changes in the environment.

Zoobenthos and zooperiphyton are distinguished by stable localization at certain habitats for a long time and hence they are suitable for observing the anthropogenic succession and the processes of self-purification of aquatic ecosystems. The composition of zoobenthos includes the most long-lived (excluding fish) groups of aquatic organisms, namely, molluscs and oligochaetes, which make up a large proportion of zoobenthos biomass in many water bodies and watercourses. Therefore, they are good indicators of chronic pollution and ecosystem stability. Zoobenthos is the basis for biomonitoring of the surface waters in the countries of European Community and the United States. Therefore, most bioindication methods are aimed at the study of its composition and structure.

Macrophytes, as compared to other hydrobionts, are more conservative indicators of water quality; they are more resistant to short-term pollution and are able to integrate pollution fluctuations over time. Besides, many of them are non-specific concentrators of elements. Thus, macrophytes are a good object for long-term monitoring ${ }^{[-8]}$.

\section{Materials and techniques}

In the post-flood period, from September 17 to September 25, 2013, the field investigation of watercourses, draining the territory of the cosmodrome, were carried out (Figure 1). A total of 12 watercourses were studied. In the period from June 28 to July 2, 2014 (prior to summer-autumn flood), nine watercourses were examined. The standard hydrobiological methods were used for sampling, initial processing and laboratory analysis ${ }^{[9]}$.

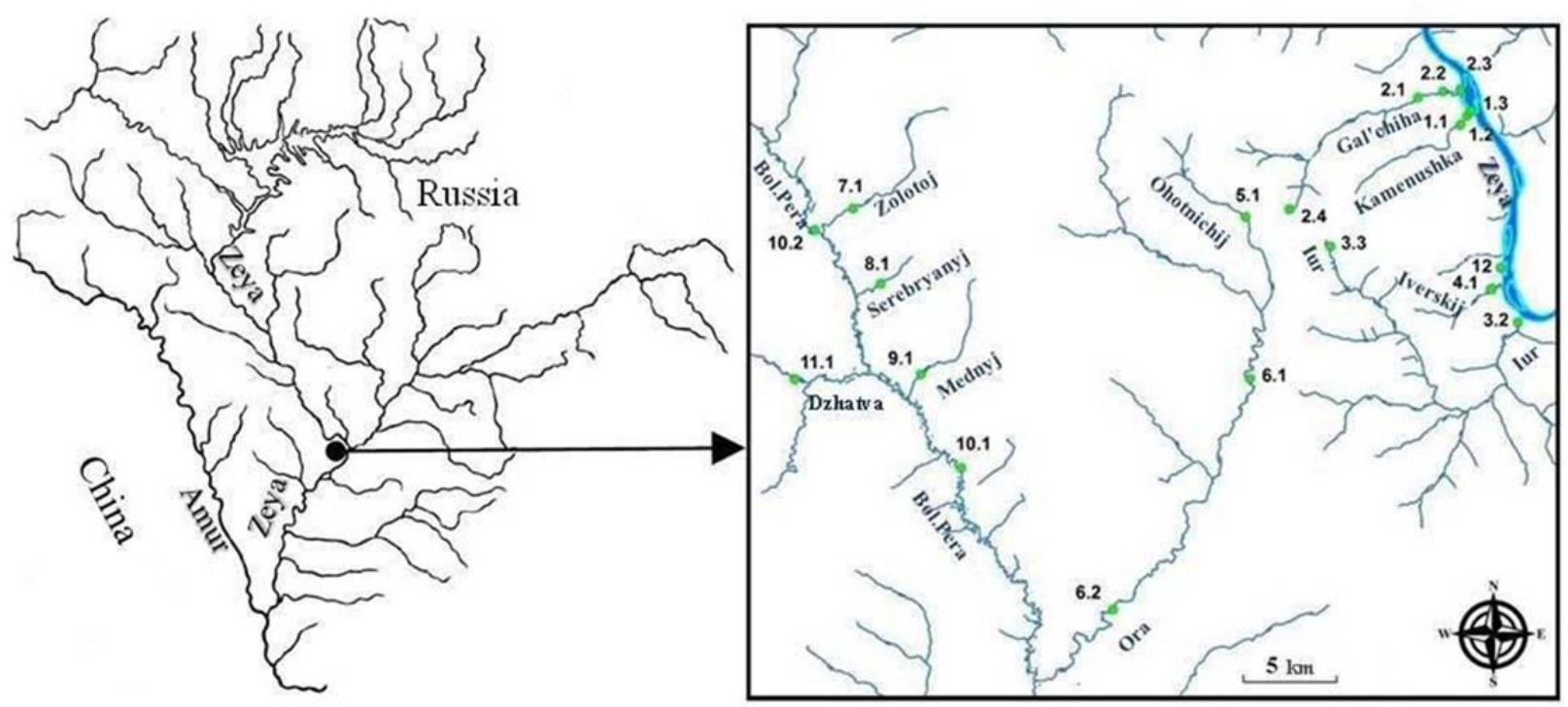

Figure 1. Map of sites where hydrobionts was sampled. 


\section{Results and discussion}

\subsection{Structure and composition of aquatic communities}

Watercourses at the Vostochny Cosmodrome are characterized by high taxonomic diversity of hydrobionts. In the course of research, 106 species of phytoplankton algae represented by 110 intra- specific taxa were found. In peripheral and benthic algoflora, 153 species of algae from seven groups; 38 species of macrophytes from five groups and 20 families; 60 species of planktonic animals and 108 species of benthic invertebrates from 5 classes were revealed (Table 1).

Table 1. Hydrobiological features of streams at launch site of the Vostochny Cosmodrome (28.06-02.07. 2014)

\begin{tabular}{|c|c|c|c|c|c|c|c|c|c|c|c|c|c|c|}
\hline \multirow[t]{2}{*}{ Watercourse } & \multicolumn{4}{|c|}{ Phytoplankton } & \multicolumn{3}{|c|}{ Phytoperiphyton } & \multirow{2}{*}{$\begin{array}{l}\text { Macrop } \\
\text { hytes } \\
\text { n }\end{array}$} & \multicolumn{3}{|c|}{ Zooplankton } & \multicolumn{3}{|c|}{ Zoobenthos } \\
\hline & $\bar{n}$ & $\begin{array}{l}\mathbf{N}, \text { th. } \\
\text { cells } / \mathbf{d} \mathbf{m}^{3}\end{array}$ & $\begin{array}{l}\text { B, mg/d } \\
\mathbf{m}^{3}\end{array}$ & $\begin{array}{l}\text { Chl. a, } \\
\mathrm{mg} / \mathrm{m}^{3}\end{array}$ & $\mathbf{n}$ & $\begin{array}{l}\mathbf{N}, \text { bi } \mathbf{l} . \\
\text { cells } / \mathbf{m}^{2}\end{array}$ & $\mathrm{~B}, \mathrm{~g} / \mathrm{m}^{2}$ & & $\mathbf{n}$ & $\begin{array}{l}\mathbf{N}, \text { spe- } \\
\text { cies } / \mathbf{m}^{3}\end{array}$ & $\begin{array}{l}\mathrm{B}, \\
\mathrm{mg} / \mathbf{m}^{3}\end{array}$ & n & $\begin{array}{l}\mathbf{N}, \text { th. spe- } \\
\text { cies } / \mathbf{m}^{2}\end{array}$ & $\begin{array}{l}\mathrm{B}, \\
\mathrm{g} / \mathrm{m}^{2}\end{array}$ \\
\hline Galchikha river & 13 & 10.1 & 22.8 & 1.21 & 34 & - & 395 & 6 & 9 & 1,525 & 4.18 & 7 & - & - \\
\hline Iversky stream & 8 & 6.20 & 2.4 & 0.20 & 47 & 19.3 & 1.24 & 5 & 12 & 250 & 9.63 & 6 & 0.07 & 0.19 \\
\hline Okhotnich stream & 10 & 12.7 & 13.6 & 0.85 & 25 & 12.1 & 0.51 & 5 & 9 & 210 & 0.98 & 6 & 0.14 & 0.14 \\
\hline Ora river & 28 & 47.9 & 102 & $\begin{array}{l}1.27 \\
-2.5 \\
4\end{array}$ & 46 & 33.5 & 1.23 & 10 & 23 & 470 & 6.53 & 20 & 4.14 & 6.71 \\
\hline Zolotoy & 21 & 51.6 & 266 & 1.15 & 27 & - & 276 & 14 & 13 & 320 & 0.95 & 6 & 0.43 & 0.43 \\
\hline Serebryan stream & 18 & 28.4 & 1040 & 0.89 & 21 & 965 & 13.3 & 7 & 11 & 480 & 2.13 & 10 & 12.42 & 16.2 \\
\hline Medny stream & 18 & 21.6 & 46.6 & 1.06 & 17 & - & 1260 & 4 & 6 & 160 & 0.42 & 11 & 2.50 & $\begin{array}{l}6.3 \\
5\end{array}$ \\
\hline Bols & & 182 & 358 & 2.57 & 26 & 92,4 & 3.2 & 6 & 13 & 11 & 0.25 & 19 & 0.35 & 3.64 \\
\hline Zeya river & 38 & 74.2 & 57.6 & 1.83 & 37 & 147 & 2.43 & 8 & 18 & 7,000 & 4.38 & 13 & 0.05 & 0.18 \\
\hline
\end{tabular}

Note: $\mathrm{n}$-total number of species; N-number (maximum); B-biomass (maximum); Chl. a-Chlorophyll "a" concentration. «-»-no data available.

Diatoms prevailed in phytoplankton and phytoperiphyton. Based on the previous studies (September 2013), the proportion of diatoms in phytoplankton made up $79 \%$ in the post-rainfall flood, while during the summer low water (July 2014), only $64 \%$, with an increase of green algae (18\%). Phytoplankton of the studied streams of the Zeya basin demonstrates the features of typical river plankton with the dominance of diatoms, and among them - the benthic forms. The taxonomic diversity of macrophytes in the streams under study is around half of the total species given by Ya.V. Bolotova $^{[10]}$ for aquatic flora of the Lower Zeya. The flowering plants dominate in number of species (29 species), among which monocotyledons prevail (55\%) which is typical for most hydrophilic flora of the Holarctic, including the aquatic flora of the Amur region ${ }^{[11,12]}$. The highest aquatic vegetation fully reflects the features of the monsoon climate and hydrological regime of the rivers studied. The monsoon climate and the bogginess of catchments are responsible for the dominance of moss, sedge and cereals in the flora, while the marginal water plants and marsh plants are dominant in the eco-biomorphological structure ${ }^{[13]}$.
The monsoon climate affected the overgrowing of the studied streams, which demonstrate the spotty and semi-aquatic spotty overgrowing despite the shallow water and the occurrence of a large number of quiet pools. The banks are covered with sedge-grass herbs (Carex rhyn-chophysa C. A. Mey, Bolboschoenus sp., Agrostis gigantea Roth), in the channel on stony ground at a depth of $0.1-0.3 \mathrm{~m}$ the aquatic moss-like plants (Marchantia polymorpha L.,

Leptodictyum riparium (Hedw.) Wamst.), and the knotgrass (Hippuris vulgaris L.) dominate; in quiet areas -the buttercup (Ranunculus gmelinii DC.). On wet coastal slopes (supralittoral), the mosses (Rhizomnium punctatum (Hedw.) T. Kop., Sphagnum squarrosum Crome) prevail, among which the violet (Viola epipsiloides A. et D. Love) is often found ${ }^{[14]}$.

The zooplankton biocenosis of most streams is multispecies, the evribionts and less phytofilous forms of rotifers, copepods and Cladocera crustaceans (9-23 species) constitute the major portion; a small number of biocenosis species (six species) was found in Medny stream. The watercourses were characterized by significant development of benthic forms feeding on vegetable detritus 
(harpacticoid and nektobenthonic forms of Cyclopoida) that is apparently typical of such ecosystems in the region ${ }^{[15,16]}$. The zooplankton composition of all watercourses, except for Zeya, showed the absence of Diaptomidae family. Considering that all of the watercourses had a favorable oxygen regime and neutral $\mathrm{pH}$, it can be assumed that among the factors limiting the development of Diaptomidae were lack of fodder (diatoms and protococcus) ${ }^{[17]}$ and high flow velocity, especially during the flood periods. The number and biomass of zooplankton in streams and small rivers, as a rule, is much lower than in medium-size and large rivers on the territory of the cosmodrome.

In the benthos of many watercourses, the chironomid larvae and the oligochaetes were dominant. Such species composition and structure of zoobenthos in watercourses under study are characteristic of the Zeya basin ${ }^{[18,19]}$. Almost $100 \%$ of the chironomidae species revealed are on the list of chironomidae, previously identified in the Zeya and Amur basins, the same is true for stoneflies, while the share of mayflies makes up $68 \%{ }^{[20-22]}$. The level of development of bottom zoocenoses of the majority of watercourses is extremely low and very low. Low and moderate levels of development are peculiar to Ora River and Serebryany and Medny streams.

\subsection{Bioindication evaluation of water quality}

In terms of biomass of phytoplankton, zoobenthos and chlorophyll a (CHL a), most of watercourses are oligotrophic water bodies. The relative pigment indices are indicative of the predominance of $\mathrm{ChL}$ a over the yellow pigment (carotenoids) at the most sampling points. This suggests favorable conditions for the development of algae in the water, despite the low abundance (by concentration of $\mathrm{ChL}$ a). According to the complex ecological classification of land water quality, the concentration of CHL a in all watercourses during the summer-autumn period corresponds to the I class of water quality ("very clean").

In terms of the occurrence of species-indicators of saprobity in phytoplankton, phytoperiphyton, and zooplankton, the organic pollution was evaluated. The saprobity index corresponded to the oligo-beta-mesosaprobic zone, water purity classes were II and III ("clean" and "moderately polluted" water). According to the taxonomic structure and the level of zoobenthos development, the water quality in rivers also corresponded to the II and III quality classes ("pure" and "moderately polluted"), in streams - III and IV ("moderately polluted" and "polluted"). Most likely the biotic indices of small streams are too low, however, this benthos structure provides a background condition.

\subsection{Recommendations on the organization of watercourses monitoring at the Vostochny Cosmodrome}

The system of ecological monitoring of the launch site should become a component of the Russian Space Agency environmental monitoring. The FSUE "Center for operation of ground-based space infrastructure facilities" is the head enterprise for environmental monitoring of the "Baikonur" launch site and the booster rocket drop zones, i.e., it is responsible for departmental environmental monitoring. In order to achieve this goal, the company has established the Department of environmental safety of ground-based space infrastructure facilities.

Within the framework of particular objects of space infrastructure (e.g., cosmodromes) the systems of operational environmental monitoring (OEM) are formed as the subsystems of departmental environmental monitoring. Monitoring of sources of anthropogenic influence of the Baikonur cosmodrome differs little from the monitoring of industrial facilities ${ }^{[23]}$. The OEM should be implemented so that it can be included in the system of the state monitoring of the Russian Federation, regional monitoring systems, primarily of the Amur oblast. These monitoring systems should be legally and methodically coordinated, and act in a coordinated fashion.

In the Federal Service for Hydrometeorology and Environmental Monitoring of Russia (Roshydromet) system, water quality control stations are divided into 4 categories. To collect full-scale data on the "Vostochny" launch site, it is advisable to organize structural units similar in function to the 
station of the III category, which "are located in the cities with a population of up to 0.5 million people, on the closing sections of large and medium-size rivers, in the mouths of polluted tributaries of large rivers and water bodies, in the areas of organized wastewater discharge, resulting in a low level of pollution",[24].

The frequency of hydrobiological observations at the launch sites is as follows: monthly studies are carried out during the vegetation period on the shortened program no.1 (phytoplankton, zooplankton and periphyton) on large water bodies and on the shortened program no.2 (zoobenthos) on small rivers; the complete program is implemented quarterly for phytoplankton, zooplankton, periphyton, zoobenthos, bacterioplankton and macrophytes. In the drop zones, it is worthwhile to conduct the hydrobiological monitoring in accordance with the water quality class: I-II-III classes, annually, VI class - annually or with an interval of 2-3 years for 1-2 indicators, V-VI classes - with an interval of $2-3$ years for $1-2$ indicators.

\section{Conclusion}

The analysis of the research results conducted in 2013-2014 shows that the water-ecological situation in the launch site of the Vostochny Cosmodrome is relatively satisfactory. No significant impact of the construction of cosmodrome facilities on the ecosystems of watercourses in the region was revealed.

By hydrobiological characteristics, the watercourses are typical small and medium-sized waterstreams of the Zeya river basin. Significant flow of watercourses due to the monsoon climate, as well as high oxygen content, the absence of pollution with organic substances and heavy metals provides a great potential for physical and chemical self-purification, despite the low level of biocenoses development.

Hydrobiological methods should be used for comprehensive environmental monitoring of water bodies at the cosmodrome. The system of biological monitoring of the cosmodrome, as a part of the departmental environmental monitoring of Roscosmos, should be coordinated with the Roshydromet monitoring.

\section{Conflict of interest}

The authors declare that they have no conflict of interest.

\section{References}

1. Puzanov AV, Sambros VV, Bezmaternykh DM, et al. Assessment of environmental impact of the Vostochny Cosmodrome construction. Priority Issues of Environmental Safety in the Drop Zones of Siberian Region and Ways of Their Solution: Proceedings of Scientific-Practical Workshop; 2016 June 22-24; Elanda village (Republic of Altai). Moscow: Sputnik Publisher; 2016. p. 110-118.

2. Tiunova TM (editor). Hydroecological monitoring of the impact zone of the Zeya hydrosystem. Khabarovsk: Publishing House of FEB RAS; 2010. p. 354.

3. Puzanov AV, Kirillov VV, Bezmaternykh DM. Assessment of the current water-ecological situation at the launch site of the Vostochny Cosmodrome. World of Science, Culture and Education Journal 2014; 3: 415-418.

4. Puzanov AV, Kirillov VV, Bezmaternykh DM, et al. Ecological status of streams in the area of the Vostochny Cosmodrome. Geography and Natural Resources 2017; 2: 66-72.

5. Bezmaternykh DM, Kirillov VV, Kirillova TV. Indication of ecological state of water bodies by composition and structure of biocenoses. Inter-Regional Medical-Ecological Forum: Proceedings. Barnaul: AzBuka; 2006. p. 75-79.

6. Ziglio G, Siligardi M, Flaim G (editors). Biological monitoring of rivers: Applications and perspectives. England, Chichester: John Wiley \& Sons Ltd.; 2006. p. 469.

7. Jonson RK. The indicator concept in freshwater biomonitoring. In: Cranston P (editor). Chironomids: From genes to ecosystems. Melbourne: CSIRO Publication; 1995. p. 11-30.

8. Rosenberg DM, Resh VH (editors). Freshwater biomonitoring and benthic macroinvertebrates. New York: Chapman \& Hall; 1993. p. 488.

9. Guidelines for hydrobiological monitoring of freshwater ecosystems. St. Peterburg: Giodrometeoizdat; 1992. p. 318.

10. Bolotova YaV. Aquatic plants of Amur oblast: Author's abstract. Blagoveshchensk; 2009. p. 23

11. Gapeka AI. Riparian-aquatic vegetation of the lower Amur. Higher Aquatic and Riparian-Aquatic Plants: Proceedings of the I All-Union Conference. Kiev; 1977. p. 6-8.

12. Kozhevnikov AE. Biological diversity of vascular plants of the Russian Far East: Main floristic and systematic parameters. Bulletin of FEB RAS 2003; 3: 39-53.

13. Zarubina EYu. Species diversity and structure of the higher aquatic vegetation of the Zeya lower reaches. Readings in memory of V.Ya. Levanidov 2014; 6: 
$250-256$.

14. Zarubina EYu. Features of formation of vegetation cover on small rivers of Amur oblast in monsoon climate. Ecology of Small Rivers: Biodiversity, Environment, Protection: Proceedings of All-Russia Conference. Yaroslavl: Philigran’ Publisher; 2014. p. 151-154.

15. Ermolaeva NI. Current state of zooplankton in watercourses of the Zeya lower reaches. Vostochny Cosmodrome Future of Space Industry of Russia: Proceedings of the II All-Russia Scientific-Practical Conference. Blagoveshchensk: Blagoveshchensk State Pedagogical University Publisher 2013; 1: 184-191.

16. Ermolaeva NI. Structure of zooplankton in tributaries of the Zeya lower reaches after extreme flood. Readings in memory of V.Ya. Levanidov 2014; 6 : 211-219.

17. Mitrofanova EYu. The state of phytoplankton in small watercourses of the Zeya basin in the autumn flood of 2013. Vostochny Cosmodrome-Future of Space Industry of Russia: Proceedings of the II All-Russia Scientific-Practical Conference. Blagoveshchensk: Blagoveshchensk State Pedagogical University Publisher 2013; 2: 58-61.

18. Bezmaternykh DM, Vdovina ON. Zoobenthos of watercourses in launch site of the Vostochny Cosmodrome (Amur oblast). Readings in memory of
V.Ya. Levanidov 2014; 6: 88-98.

19. Bezmaternykh DM, Vdovina ON. Current state of benthic invertebrate communities in watercourses of launch site of the Vostochny Cosmodrome. Fish Farming and Fisheries Journal 2015; (1-2): 8-12.

20. Makarchenko EA, Makarchenko MA, Zorina OV, et al. Preliminary data on fauna of chironomids (Diptera, Chironomidae) of the Amur River basin. Freshwater ecosystems of the Amur River basin. Vladivostok: Dal'nauka Publisher; 2008. p. 189208.

21. Teslenko VA. Fauna and distribution of stoneflies (Insecta, Plecoptera) in the Zeya basin. Freshwater ecosystems of the Amur River basin. Vladivostok: Dal'nauka Publisher; 2008. p. 151-171.

22. Tiunova TM. Dayflies (Insecta, Ephemeroptera) of the Zeya river basin (Amur oblast). Freshwater ecosystems of the Amur River basin. Vladivostok: Dal'nauka Publisher; 2008. p. 172-188.

23. Kondratiev AD, Krechetov PP, Koroleva TV, et al. The Vostochny Cosmodrome as the object of nature management. Moscow: Pelikan Publisher; 2008. p. 176.

24. Organization and carrying out monitoring observations of surface water pollution on the Roshydromet network. Russian patent. P 52.24.309-2004. 2006 Jan 1. 